\title{
A PESQUISA HISTÓRICA EM GOIÁS ( $\left.{ }^{\star}\right)$.
}

\author{
GILKA VASCONCELOS F. DE SALLES \\ do Instituto de Ciências Humanas e Letras da Univer- \\ sidade Fede: al de Goiás.
}

INTRODUÇÃO :

O propósito de colaborar no estudo das fontes informativas para maior enriquecimento da Pesquisa Histórica no Brasil, leva-nos a apresentar a súmula do que, até o momento, tem sido feito em relação à Historiografia Goiana .

Situado em posição geográfica menos favorecida do que os outros Estados litorâneos do Brasil, Goiás foi conquistado e colonizado quase dois séculos depois do assentamento português às margens do Atlântico. Devido, ainda, a sua localização geográfica em relação às outras unidades políticas brasileiras, tornou-se uma das mais extensas, uma das menos povoadas e precàriamente aquinhoadas de vantagens econômicas.

Colocado entre $6^{\circ}, 2^{\prime}$ ' latitude sul è $326^{\circ}, 335^{\prime}$ longitude oeste, estende-se, de norte a sul, em mais de 1800 quilômetros (1).

Os grandes espaços, vazios de aglomeração humana, vão se povoando paulatinamente. A onda migratória, vem se avolumando mais, a partir da segunda metade do século XX, com a transferência da Capital Federal para o interior do paîs. Trazem, os recentes povoadores, nova experiência e o dinamismo de seus antigos rincões.

As possibilidades ecológicas ainda jazem $\mathrm{em}$ parte inexploradas, em apreciável parte do território. E' de aguardar-se que, da conjunção harmoniosa da cultura e ação de seus tradicionais habitantes, e dos que se transferem para a nova morada, seja possível maior desenvolvimento.

(*). - Comunicação apresentada na mesa-redonda sôbre o "Estado atual da pesquisa histórica no Brasil", realizada em 5 de julho de 1971, em Curitiba, por ocasião da XXIII Reunião anual da Sociedade Brasileira para o Progresso da Ciência (SBPC) (Nota da Redaçãa).

(1). - SOUZA (LUIS ANTÔNIO DA SILVA), O Descobrim $n$ to da Capitania de Goyaz. Publicação da Univeisidade Federal de Goiás, 1967. 
As duas Universidades - a Federal e a Católica - atraem estudantes de vários Estados que se lhe confinam, principalmente das comunidades menos providas de recursos culturais: cidades do Triângulo Mineiro, sul do Piauí, Maranhão, Pará, Amazonas e oeste da Bahia .

E' da colaboração dos jovens estudiosos provindos de todo Brasil, em conjunção com os estudantes e professôres locais, que novos estudos históricos estão se processando. Unindo-se, docentes e discentes, dos Departamentos de Geografia e História do Instituto de Ciências Humanas e Letras da Universidade Federal de Goiás e da Faculdade de Filosofia, Ciências e Letras da Universdiade de Goiás (Católica) foi possível selecionar as principais trezentas e sessenta e quatro obras que direta ou indiretamente, estudam os problemas históricos de Goiás, cuja resenha apresentamos no final dêste trabalho. Um acréscimo a êste está em estudo, onde serão inseridos textos documentais, estatísticas e outros dados sôbre o Estado.

\section{A HISTORIA GOIANA NO SECULO XIX}

A primeira história de Goiás foi escrita pelo cônego Luís Antônio Silva e Souza. E' uma síntese histórica e geográfica, narração que resume os sucessos ocorridos na porção Leste do Centro Oeste, desde o seu descobrimento até 30 de novembro de 1812. Fazia parte das atribuições das antigas câmaras, o segundo vereador apresentar os fatos mais importantes do seu tempo,

"a fim de perpetuar a memória do rei".

Até 1812,não foi possível qualquer crônica sôbre a capitania de Goiás, possìvelmente por não ter havido algum vereador que se dispusesse a realizar a tarefa. A incumbência foi dada ao Cônego Silva e Souza, que em dois meses a concluiu, sendo, conforme se preceituava, assinada pelo segundo vereador Custódio Pereira da Veiga - que a apresentou em $\mathbb{C}$ Conselhó e a mandou registrar. Decorre, dêste episódio, o fato de Silva e Souza ter assumido a paternidade da História Goiana (2).

$O$ Descobrimento da Capitania de Goyaz, nome da obra, foi mais tarde publicada em $O$ Patriota, jornal editado na Côrte. E' de grande

(2). - AlenCastre (J. M. P.), Anais da Provincia de Goiás, $3^{\circ}$ Trimestre de 1864. Revista Trimestral do Instituto Histórico, Geográfico e Etnográfico do Brasil. Pág. 2. 
valor, por seu pioneirismo e por ter se transformado em pedra funda-. mental, modêlo de onde partiram os outros historiadores que se the seguiram. O mesmo autor escreveu Memória Estatística da Província de Goyaz, trabalho que amplia o primeiro, dentro do mesmo quadro cronológico. Essa primeira história foi recentemente reeditada pela tipografia da Universidade Federal de Goiás.

No século passado, ainda foram publicados outros trabalhos importantes, como o de J. M. Pereira de Alencastro, Anais da Província de Goyaz, editado em 1854. Procura analisar, dentro de espírito "ilustrado" da época, o período do descobrimento e conquista e a implantação da colônia, através do sistema administrativo advindo da capitania de São Paulo. Relaciona o passado histórico dos Cąpitães-Generais com a influência clerical, onde critica o obscurantismo da metrópole e a ação da Igreja. Ilustra a obra com a inserção de documentos originais, o que a valoriza para os atuais pesquisadores. $O$ estudo se estende até o período da Independência do Brasil, mostrando seus reflexos na Capitania (3).

Raymundo José da Cunha Mattos escreve Corografia Histórica e Itinerário. Apresenta dados estatísticos de grande utilidade, muito embora não consiga cobrir, com suas informações numéricas, a totalidade dos povoados da época, possìvelmente pela falta de condições de pesquisas. Sua abordagem histórica constitui uma ampliação da primeira história goiana. Foi publicada em 1874 e datada de Traíras, aos dois de dezembro de 1824 .

Estes três primeiros historiadores da terra goiana podem ser considerados os "clássicos" de sua historiografia: pelo estilo, a disposição dos temas e a forma interpretativa.

Outros historiadores se lhe seguiram em valor histórico e dados informativos: Memória Justificativa de Henrique Silva e Memória Histórica de Pizarro. Taunay, com seu trabalho Goyaz, completa a fase de preâmbulo da historiografia dos goiases.

Um dos preciosos trabalhos do passado goiano é a Cartografia Paulista Antiga, de Afonso E. Taunay, denominada "mapa bandeirante". Ilustra o roteiro dos bandeirantes paulistas para o Centro-Oeste, a partir do século XVI. Seguem-se-lhe a Cartografia do Ministério da Guerra, do Itamarati e da Comissão de Rondon.

(3). - PALACIN (LUfS), Goiás, 1722-1822. A Estrutura e Conjuntura Numa Capitania de Minas. Inédito. Pág. 1. 
As crônicas dos viajantes ilustres que nos visitaram no século $\mathrm{XIX}$, são fontes informativas de marcado vigor. E' leitura obrigatória, quando se pretende levantar o estudo sócio-econômico de Goiás no período aurífero, e da incipiente fase de produção agríoola: No campo histórico, repetem os primeiros historiadores goianos, principalmente os compêndios de Silva e Souza.

Destacamos os principais: Johann Emanuel Pohl, com sua Viagem ao Interior do Brasil. Nos dois volumes de sua obra, relata sua passagem pela região do ouro, revelando a situação de desampararo e a decadência econômica da população, quando se extinguiu o precioso metal. Entra em contáto com os habitantes, no dia a dia de suas viagens, e relata as peculiaridades de seus costumes e o sistema de vida da época. Segue-se-lhe Auguste de Saint-Hilaire em Viagem às Nascentes do Rio São Francisco e pela Província de Goyaz. O roteiro de seu caminho situa-se nas mesmas regiões de seu predecessor, com ligeiras variantes. Sua abordagem de maior valor é a que focaliza as vias de comunicação, tão poucas, e os aspectos administrativos em 1819 , com apreciação especial sôbre o sistema agrícola e a vida da população, olhados em conjunto.

O Barão W. L. von Eschwege, com Pluto Brasiliensis, concentra-se no fulcro mineral, sem deixar de valorizar aspectos históricos e sócio-econômicos. E' estudo obrigatório para levantamento histórico da vida goiana em tôrno das minas de ouro.

Os cientistas citados percorreram a zona mais habitada pelos ambiciosos do ouro, embora já fôssem evidentes, na época, a extrema decadência, o despovoamento, e desalento dos habtiantes. Mostram, entretanto, a volta da população para a vida agrícola, no comêço do século XIX, contando já com incentivo da metrópole.

Nas últimas análises do século findo, o General Couto de Magalhães relata sua viagem realizada do Rio de Janeiro às margens do rio Araguaia, fazendo, em Goiás, o percurso que vai de Vila Boa (capital), até o grande rio mencionado. Expressa-se com admiração sôbre a flora e a fauna, descreve suas peripécias com a aproximação das tribos indígenas, estuda as questões fluviais, como solução para retirar a região de seu isolamento e preocupa-se com a mudança da capital, cuja localidade já não mais correspondia à economia agro-pastoril que se inaugurara, antes prendendo o progresso do que tentando incentivá-lo.

Oscar Leal em sua Viagem. às Terras Goianas, no final do século, percorre os caminhos que partem de Vila Boa de Goiás até Cuiabá, 
passando pelo sudoeste. Suas observações carecem de penetração e vigor. Perde tempo precioso em cogitações irrelevantes. Consegue, entretanto, descrever alguns aspectos de uma região que se povoa recentemente. Contribui para elucidar as dificuldades das viagens pelo sertão, onde as surpresas perigosas exigem do indivíduo tôdas as qualidades do seu caráter. Lança alguns dados sôbre a região pecuarista do sudoeste goiano, e caracteriza os primeiros ensaios culturais de um agrupamento humano que se encaminha para ser uma sociedade organizada.

Percorrendo o norte dos Goiases, na terceira década do século $\mathrm{XX}$, Júlio Pasternostro, em sua Viagem pelo rio Tocantins, empreende um estudo das comunicações fluviais, através do grande rio goiano. As populações ribeirinhas surgem com a peculiaridade do meio: vida econômica emergente da coleta do babaçú e dos seringais. A pobreza e a marginalidade das povoações são aspectos relevantes de sua narrativa.

Outras viagens foram realizadas, havendo novos dados elucidativos das regiões percorridas. Sua relação encontra-se no apêndice bibliográfico dêste trabalho.

\section{$*$ \\ OS HISTORIADORES DO SECULO XX.}

A primeira metade dêste século nos fornece poucos pesquisadores. Americano do Brasil, em sua Súmula da História de Goiás, faz o possível para atualizar os nossos conhecimentos do passado. Obedecendo a um plano didático, para atender à solicitação do titular da Secretaria do Interior, escreve seu compêndio para inaugurar a criação da disciplina "História de Goiás", da antiga Escola Normal da velha capital do Estado. Não pretendeu fazer algo definitivo. Semelhante ao que ocorreu a Silva e Souza, trabalhou com urgência de tempo e concluiu a obra em três meses. Sua anuência em atender à solicitação, deu-lhe a oportunidade de "abrir caminho" para mais apuradas pesquisas nos arquivos inéditos da Capital.

"É uma sintese bem trabalhada, embora não chegue a levantar problemas, nem a fazer a defesa de algum tema intensamente pensado. Apresenta um instantâneo harmonioso, que liga o início da colônia ao fim do Império".

Foi editada em 1932.

Destacamos ainda, alguns ensaios genealógicos, muito úteis para o conhecimento do período migratório dos dois séculos anteriores: 
Jarbas Jaime, com seu compêndio Do presente ao Passado, estuda a origem das famílias meiapontenses. Gelmires Reis em Genealogia Luziana reconstitui a linhagem pretérita das famílias da cidade de Santa Luzia.

Jarbas Jaime, num outro compêndio, estuda o passado de cinco cidad ̃̃os que se distinguiram pela inteligência, probidade e capacidade de trabalho, na antiga vila de Meia Ponte: Cinco Vultos Meiapontenses.

Para o estudioso da história goiana, são êstes os bons trabalhos de sua historiografia, nas primeiras décadas do século XX. Grande variedade a mais foi editada. Citamô-la, em resenha anexa.

\section{PLANO INTEGRADO DE PESQUISA SOBRE A REFORMULA- ÇÃO DA HISTÓRIA DE GOIÁS.}

Intimamente associadas com o ensino, as pesquisas programadas pelos departamentos de História de nossa Universidades, visam a reformulação da História de Goiás, através de estudos monográficos e teses.

Em fase de busca documental, os seguintes temas estão programados pelos professôres, em preparo para Mestrado e Doutoramento na Universidade de São Paulo:

\footnotetext{
1. - A cidade de Goiás no século XVIII.

2. - A sociedade e a economia de Goiás no início do século XIX.

3. - A navegação no rio Araguaia no século XVIII.

4. - Goiás, rotas e caminhos no periodo colonial.

5. - Aldeamentos indígenas em Goiás no século XVIII.

6. - O desenvolvimento sócio-econômico da Província de Goiás no Segundo Império.

7. - O Liberalismo em Goiás no século XIX.

8. - A Revolução de 1930 em. Goiás.

9. - A fundação de Goiânia.

10. - Goiás. 1722-1822 - A estrutura e a conjuntura numa capitania de Minas.
}

Este último tema já se encontra concluido, visando, o seu autor, Padre Luís Palacin Gomez, a defesa da tese para a obtenção do título de Livre-Docente na Universidade Federal de Goiás. Será editado pelo Departamento de Cultura da Secretaria de Educação e Cultura do Estado de Goiás. Este trabalho foi elaborado dentro de um plano atualizado de pesquisa histórica, onde seu autor, reconstituindo o es- 

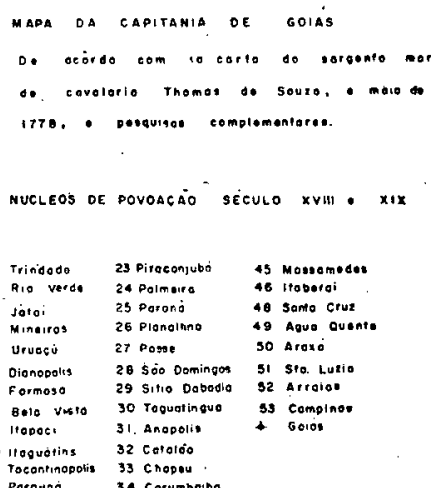

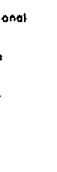

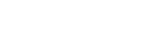


bôço estrutral do período colonial da mineração, insere o processo circunstancial da vida administrativa, política e sócio-econômica do século XVIII. E' uma das boas análises históricas, baseada em pesquisas documentais, obedecendo à moderna técnica de elaboração.

\section{$*$ \\ TRABALHO POSTUMO.}

Será lançado brevemente, de autoria do historiador Jarbas Jaime, já citado anteriormente, o Esbôço Histórico de Pirenópolis. Reconstitui a vida que emerge do antigo arraial de Meia Ponte, e segundo fulcro minerador da Província, em seu período de atração aurífera, no explendor da coraucópia e na decadência das minas, com o substitutivo da vida agro-pastoril. E' de grande valor pela exposição documental que apresenta. Possibilita, ao futuro pesquisador, interpretar fontes históricas em letra de forma, cujos documentos, muitas vêzes, já se perderam na inadequiada coletânea de seus possuidores.

\section{A DOCUMENTAÇÃO HISTORICA DE GOIAS.}

Os textos manuscritos importantes para o estudo da História Goiana encontram-se nos seguintes acervos documentais:

1. - Arquivo Histórico Ultramarino de Lisboa - Portugal.

2. - Arquivo da Torre do Tombo - Portugal.

3. - Arquivo Público de São Paulo.

4. - Arquivo Nacional do Rio de Janeiro.

5. - Arquivos Históricos da Bahia, Maranhão e Pará.

6. - Arquivo Público Mineiro - Belo Horizonte.

7. - Serviço de Documentação do Estado de Goiás.

8. - Arquivo do Museu das Bandeiras - cidade de Goiás.

9. - Cartórios de primeiro oficio de Goiás, Pirenópolis, Santa Luzia, Corumbá, Jatai, Rio Verde, Mineiros; Caiapônia.

10. - Arquivos das Prefeituras das cidades citadas no item 9.

11. - Cartório de Registro de Propriedade das mesmas localidades citadas acima.

12. - Arquivo Paroquial de Goiânia, Pirenópolis, Goiás, Corumbá.

As cidades do norte goiano são pobres em fontes documentais. A maioria foi destruída pelo tempo e a incúria dos responsáveis pelos 
arquivos oficiais. Pode-se contar, apenas, com a documentação particular, esquecida em canastras e baus, constando de testamentos, escrituras e cartas epistolares.

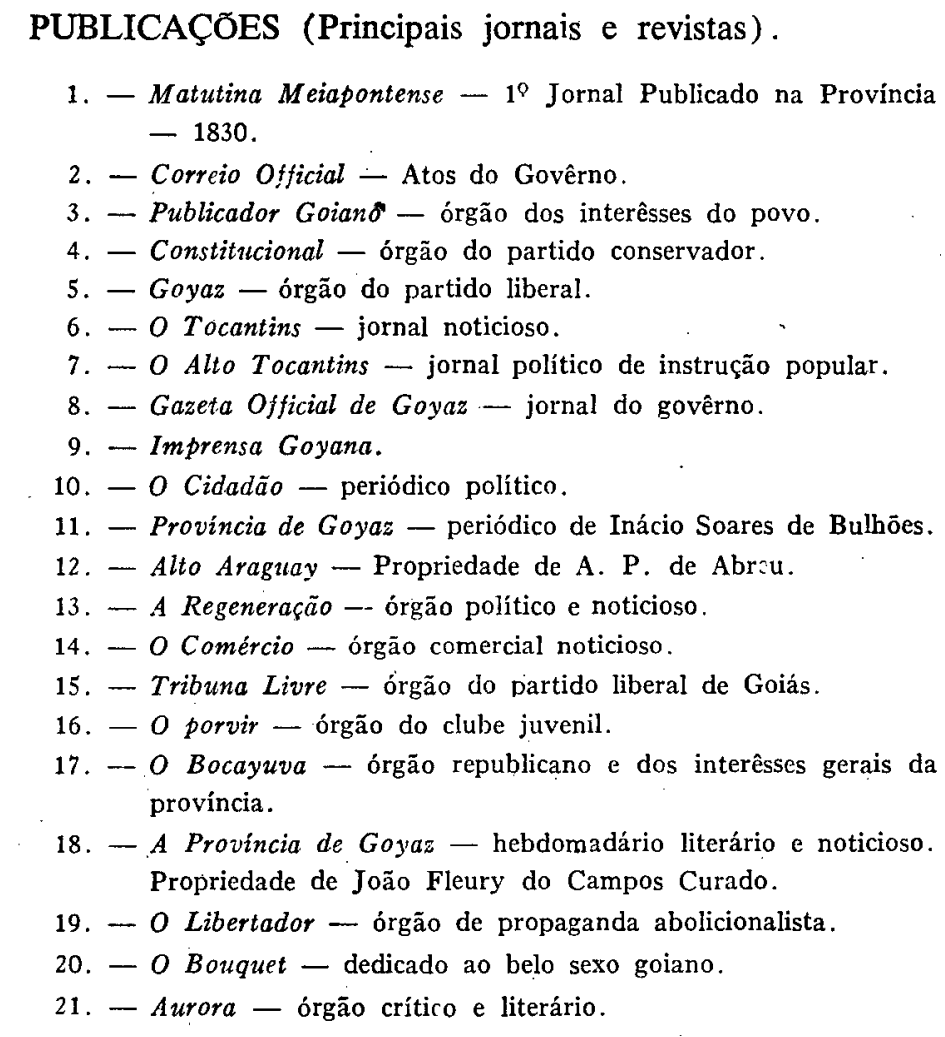

\section{PANORAMA ATUAL E POSSIBILIDADES FUTURAS.}

As nossas condições de pesquisa histórica ainda se encontram em fase de esbôço. A partir do ano findo, foi possível, aos professôres das Universidades, pensarem em extrair tempo para trabalho sério de investigação documental.. Os acervos de textos ainda se encontram em período de organização. Os orçamentos disponíveis para trabalhos mais dispendiosos, não estão definitivamente programados. 
Com a paulatina transformação que se opera na vida universitária, voltando-se os órgãos dirigentes para maior amparo à ciência, ao incentivarem financeiramente os pesquisadores para disporem de tranqüilidade econômica para o trabalho, está havendo um despertar promissor para a historiografia de Goiás. E' necessário, entretanto, um trabalho conjugado com a Diretoria do Patrimônio Histórico e Artístico Nacional. Os nossos arquivos estão muito mal amparados. Não há técnicos especializados que se ocupem da recuperação e catalogação dos documentos .

A Universidade de São Paulo, através do Centro de Documentação Histórica de Amparo à Pesquisa do Estado de São Paulo, microfilmou a documentação catalogada no Arquivo do Museu das Bandeiras, naquilo que se relaciona com o período colonial e imperial da história goiana. Ainda permanecem empilhados, aguardando o manuseio inicial de seleção, parte da época do Império e do período republicano.

Os professôres do Departamento de História do Instituto de Ciências Humanas e Letras realizam o levantamento das fontes primárias contidas nos códices manuscritos da época colonial, no serviço de documentação do Estado de Goiás .

As duas Universidade, conjugadas, poderão realizar eficaz trabatho de elaboraçã̃o científica no campo das Ciências Humanas. A Universidade Católica inaugurará a sua Biblioteca Central, a partir de agôsto de 1971. Haverá um órgão planejado de biblioteconomia, o que facultará a realização de convênios entre aquêle serviço e as Unidades Universitárias Federais do Estado.

O Instituto de Ciências Humanas e Letras da Universidade Federal de Goiás, realizará convênio com a Secretaria de Administração do Estado de Goiás para responsabilizar-se, em local apropriado e técnicos preparados para o trabalho, pelo total acêrvo documental do Estado, atualmente sob a tutoria do Arquivo Geral do Estado de Goiás, sem condições de atendimento adequado.

As medidas planejadas poderão trazer melhores condições futuras de investigação documental. Algo foi realizado, e muito ainda deverá ter continuidade. Aguardemos.

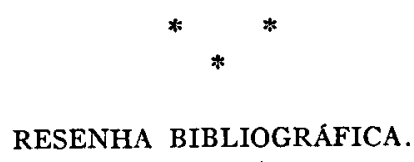

Coletada pelo Prof. Sérgio Paulo Moreyra.

1) ABREU (CAPISTRANO de). - Caminhos Antigos e Povoamento do Brasil. Sociedade Capistrano de Abreu, 1954. 
2) ABREU (CAPISTRANO de). - Capitulos de História Colonial. Sociedade Capistrano de Abreu, 1954. Inúmeras referências valiosas com respeito a Goiás.

3) ABREU (CAPISTRANO de). - Publicação comentada do roteiro da bandeira de 1722 feito pelo alferes José Peixoto da Silva Braga. Gazeta Literária, 1883, Rio de Janeiro págs. 62-65 e 110-113.

4) ABREU (S. FROES). - A Riquêza Mineral do Brasil. De pouco valor.

5) ALEnCAStre (J. M. P.). - Anais da Província de Goiás. Revista do I.H.G.B., t. 27, 1864. Indispensável. Foi o primeiro a emitir conceito sôbre o que viu e a criticar outros historiógrafos.

Ler a carta do Ouvidor - litígio.

Ler a carta de $\mathrm{P}$. Perestrele - religioso.

Ler a carta de João de Melo - Guerra aos Caiapós.

6) ALENCASTRE (J. M. P. de). - Trą̧os Biográficos de Silva e Sousa. Revista do I.H.G.B., 1863.

7) ALMEIDA (CÂNDIDO MENDES DE). - A Carolina ou a difinitiva fixação de limites entre as provincias do Maranhão e Goiaz, por Cândido Mendes de Almeida. Entregue pelo autor do I.H.G.B., em 29 de outubro de 1852.

8) ALMEIDA (CÂNDIDO MENDES DE). - Memórias para a História do Extinto Estado do Maranhão, por Cândido Mendes de Almeida. Rio de Janeiro, 1860.

9) ALMEIDA (CÂNDIDO MENDES DE). - Várias citações bibliográficas inseridas no Atlas do Império do Brasil. do autor citado. Gabinete Literário. Goiás, cidade.

10) ALMEIDA (CÂNDIDO MENDES DE). - Atlas do Império do Brasil, por Cândido de Mendes Almeida. Rio de Janeiro, 1868.

11) ALMEIDA (CÂNDIDO MENDES DE). - Memórias para a História do Extinto Estado do Maranhão. Rio de Janeiro, 1874.

12) ALMEIDA (EDUARDO DE CASTRO E.).. - Inventário de documentos relativos ao Brasil, existentes no arquivo da Marinha e Uutramar de Lisboa. Anais da Biblioteca Nacional, vol. 32, 1914.

13) ALMEIDA (JOSIAS DE). - Brasil Real e Sonhado. Quase nada.

14) ALMEIDA (VICTOR COELHO DE). - Goiás, Usos, Costumes, Riquezas Naturais. São Paulo, 1944. De pouco valor, porém utilizável como informe pessoal.

15) Álvares (GERALDo TEIXEIRA). - A Luta na Epopéia de Goiânia. Rio de Janeiro, 1942.

16) AMARAL (RIBEIRO). - Sistema Hidrográficos do Rio Maranhão, Lagos e Lagoas (1897). Cit. Zoroastro. Como quase tudo que Zoroastro cita, não 
vem acompanhado de informações suficientes que permitam identificar ou localizar a obra.

17) AMIRTAGE (JOAO). - História do Brasil. Ed. Valverde.

18) ANAIS.

Anais da Escola de Minas de Ouro Prêto.

19) ALDREONI (ALDO). - Relatório de Uma Viagem Realizada no Baixo e Médio Tocantins. Goiânia, 1949.

20) ARAÚJo (JOSÉ de SOUZA AZEVEdo PIZARRO E). - Memórias Históricas do Rio de Janeiro e das Provincias Anexas à Jurisdição do Vice-Rei do Estado do Brasil. Imprensa Régia, 1820-1822.

Diz Alencastre que o Monsenhor Pizarro, copiou o que diz sôbre Goiás, de Silva e Souza.

21) ARTIAGA (ZOROASTRO). - Araguai e Tocantins, Caminho da Riqueza. 1946: Obra muito pequena, para conter reflexões duráveis.

22) ARTTAGA (ZOROASTRO). - Uma Paz Duradoura e um Herói Esquecido. In "Revista de Educação e Saúde". No 27-28, 1946.

23) ARTIAGA (ZOROASTRO). - Monografia Corográfica e Histórica da Nova Capital de Goiás. Inf. sôbre Goiânia.

24) ARTIAGA (ZOROASTRO). - Coletânia de Documentação Relativa d̀ História do Estado de Goiás. O exemplar consultado, não contém documentação, como o nome faz supor.

25) ARTIGA (ZOROASTRO). - Geografia Econômica, Histórica e Descritiva do Estado de Goiás. 1951. Obra extremamente eclética...

26) ARTIGA (ZOROASTRO). - Sintese da História e da Geografia de Goiás. 1958. Quase nada.

27) ARTIGA (ZOROASTRO). - Depoimento histórico e Roteiros.

28). ARTIGA (ZOROASTRO). - Dos Indios do Brasil Central. 1947. De baixo valor. Pouco critério e quase nenhum caráter científico do autor. Baldus o critica severamente.

29) ARTIGa (ZOROASTRO). - História de Goiás. De baixo valor. Pouco critério e quase nenhum caráter científico do autor. Baldus critica severamente.

30) AUDRIN (JOSÉ M.). - Entre Sertanejos é Índios do Norte. Biografias do Bispo Missionário D. Domingos Carreret, O. P. Rio de Janeiro, 1947. Biografia do $1^{\circ}$ Bispo Dominicano do Araguaia e $1 .^{\circ}$ Bispo do Tocantins.

31) AZEVEDO (AROLDO de). - Vilas e cidades do Brasil Central. Faculdade de Filosofia da Universidade de São Paulo, 1956.

32) AZEVEDo (CORDOLINO). - Terra Distante. Rio de Janeiro, 1925. De pouco valor. Contém, entretanto, observações sôbre o Estado, na época de sua visita. 
33) AZEVEDO (FRANCISCO FERREIRA DOS SANTOS). - Amuário Histórico, Geográfico e descritiva do Estado de Goiás. Uberaba, 1910.

34) AZEVEDO (MARQUES M. E.). - Apontamentos Histórcios, Geograficos, Biográficos, Estatísticos e Noticiosos da Província de São Paulo. Rio de Janeiro, 1879.

35) BAENA (ANTÔNIO LADISLAO MONTEIRO). - Resposta ao $\mathrm{Ilm}^{\varphi} \cdot \boldsymbol{e}$ Exm. Herculano Ferreira Pena, Presidente da Provincia do Pará, sôbre a comunicação mercantil entre a dita província e a de Goiás. Revista do I.H.G.B., X, $1848-2^{\text {a Edi. } 1870 .}$

36) BALDUS (HERBERT). - Bibliografia Critica da Etnologia Brasileira. São Paulo, 1954. Neste roteiro bibliográfico há informações sôbre inúmeras publicações sôbre Goiás.

37) BALDUS (HERBERT). - Ensáios de Etnologia Brasileira. São Paulo, 1937.

38) BARATA (FRANCISCO JOSE RODRIGUES). - Memórias em que mostra, algumas providências tendentes ao melhoramento da agricultura e comércio da Capitania de Goiás, escrita e dedicada ao Conde de Linhares por Francisco José Rodrigues Barata, Sargento-mór da Capitania do Pará. Revista do I.H.G.B., 11.

39) BARROS (F. BORGES DE). - A Margem da História da Bahia (bandeirantes baianos). Bahia, 1918.

40) BASTOS (MANOEL JOSE DE OLIVEIRA). - Roteiros da Cidade de Santa. Maria do Belém do Grão-Pará, pelo Rio Tocantins. Rio de Janciro, 1811.

41) BERSEDO (BERNARDO PEREIRA). - Anais Históricos do Estado do Maranhão por Bernardo Pereira Bersedo, Governador e Capitão General que foi do mesmo Estado e Marzagão. 1849. Ed. de Gonçalves Dias.

42) BETENDORF (JOÃO FELIPE). - Crônica da Missão dos Padres da Companhia de Jesus, no Estado do Maranhão. Revista I.H.G.B., LXXII, parte 1 - 1909. Rio de Janeiro, 1910.

43) BOLETINS.

Coleção de Boletins do Instituto Agronomico de Campinas.

44) BOLETINS.

Coleção de Boletins da Comissão Geográfica e Geológica de São Paulo.

45) BRANDÃo (ANTÔNIO JOSÉ DA COSTA). - Almanaque da Provincia. 1886.

46) BRASIL (AMERICANO DO). - Sìmula de História de Goiás. De valor restrito, como o próprio autor reconhece no seu prefácio. Foi feito para atender à necessidade de um livro sôbre o assunto na Escola Normal.

47) BRASIL (AMERICANO DO). - No convivio com as traças. 1920. Traz alguns informes de valor. 
48) BRASIL (AMERICANO DO). - Questão de Limites Goiás-Pará. 1920. Conferência de tom polêmico, realizada como réplica a pronunciamento feito por um representante paraense, no Rio de Janeiro.

49) BRASIL (AMERICANO DO). - Pela Terra Goiana. 1920. Discursos e Pronunciamentos parlamentares, profcridos pelo autor na Câmara Federal. Alguns dêles são realmente de mérito.

50) BRASIL (AMERICANO DO). - O Brigadeiro Felipe. Goiás, 1920. Tudo o que se escreveu sôbre o Brigadei: o Felipe Xavier Curado, tem valor muito relativo, dada a pouca vivência dos Marechais com a nossa terra. Entretanto, seja como fruto de uma época de explendor, seja como glória da terra, deve-se estudar a biografia dêle, o primeiro brasileiro a se alçar ao posto máximo da carreira militar, o primeiro dignatário da Grã Cruz da Ordem do Cruzeiro do Sul.

51) BRASIL (AMERICANO DO). - História de Goiás. Inédita. Dcsconhece-se o paradeiro dos originais. No museu de Goiás, há diversos materiais dêste Americano.

52) BRASIL (AMERICANO DO). - Cunha Matos em Goiás. Revista do I.H.G.B. - tomo 96, vol. 150, (1924). Rio de Janeiro, 1927.

53) BRENA (ANTÔNIO LADISLAO MONTEIRO). - Um trabalho sôbre a Comunicação Mercantil, entre a Provincia do Pará e a de Goiás, apresentada ao I.H.G.B., em 15 de junho de 1848.

54) BRITO (JOSÉ INÁCIO XAVIER DE). - Mensagem do Presidente do Estado à Câmara Estadual de Deputados. Goiás, 1895. Interessante pelo registro da situação da administração à época, posto que do ponto de vista oficial,

55) BRUNO (HERNANI DA SILVA). - História do Brasil - Amazônica. 1967. Faz refee ência à Goiás.

56) BULHõES (AUGOSTO DE). - Leopoldo de Bulhões. Biografia do ilustre goiâno, com referências que ajudam a formar um quadro da vida Província à época da juventude.

57) BULLOCK (S. C.). - Tocantins and Araguaia Rivcrs. The Geographie Jurnal, 63 London 1924.

58) BUSCA LIONI (LUIGI). - Una Escursione Botanica nell'Amazonia. Bolletine della Societá Geográfica Italiana. Série IV. vol. 2, anno 35, vol. 38. Roma, 1901.

59) CAIADO (BRASIL RAMOS). - Mensagem - 1928. Informações Oficiais.

60) CAIEIRO (JOSÉ). - Jesuitas do Brasil e da India. Academia Brasileira de Lêtras. Bahia, 1936. O excmplar que consultamos, pertence a Frei Simão, refere-se às Minas de Goiás, como repartição da Capitania de São Paulo. Há também referências a jesuítas que chegaram até nosso território, pelo Maranhão. 
61) CHAVES (CAMILO). - Caiapônia.

62) CALMON (PEDRO). - A Conquista: História das Bandeiras Bahianas. - Rio de Janeiro, 1929.

63) CALOGERAS (PANDIÁ). - As Minas do Brasil e sua Legislą̧ão. Imprensa Nacional, 1904. Importantíssimo pelas consequêencias sociais da Legislação.

54) CAMARgo JR. (SEbAStião DANTE DE). - Problemas do Oeste. Rio de Janeiro, 1948. Contém Documentos Transcritos. O Assunto é fronteiras de Goiás com Mato Grosso. O autor comprova os direitos de Goiás a uma faixa de território, hoje em poder do Estado de Mato Grosso.

65) CAMEllo (JOÃo ANTÔNIO CABRAL). - Notícias Práticas das Minas do Cuiabá e Goiases na Capttania de São Paulo e Cuiabá, que dá ao rev. Pe. Diogo Soares e Capitão João Antônio Cabral Camello sôbre a viagem que fez às minas de Cuiabá no ano de 1727. Revista do I.H.G.H., IV (1842).

66) CAMPOS (OSVALDO). - História do Rio Verde. Jornais de Rio Verde.

67) CARNEIRO (JOÃO ROBERTO AYRES). - Itinerário da Viagem da Expedição Exploradora e Colonizadora ao Tocantins em 1849. Anais da Biblioteca e Arquivo Público do Pará, VII, 1910.

68) CARNEIRO (JOSÉ NETTO DE CAMPOS). - Das febres em Goiás Pôrto, 1897.

59) CARVAlHo (J. B.). - Fragmentos da História de Ipameri. - Ipameri, 1958.

10) CORREA FILHO (VIRGfliO). - A Cata de Ouro e Diamantes.

71) CARTAS.

Carta a Gomes Freire - Morte de Sarzedas. Vol. III 615 (RAPM).

72) CASAL (MANOEL AYRES DE). - Corografia Brasilica ou Relação Histórico-geográfica do Brasil. Instituto Nacional do Livro, Coleção de Obras Raras, II, t. 1. Rio de Janeiro, 1945.

73) CASTANHEDE (PALMÉRIO DE CARVALHO). -Rio Maranhão Navegação de 1887. Citado por Zoroastro. Verificar com que citou, se existe.

74) CASTElnaU (FRANCIS). - Expedição às Regiōes Centrais da América do Sul. São Paulo, 1949.

75) CASTELUÃo (CONDE F. DE). - Relatório dirigido ao Ministro do Instrução Pública, pelo Conde $F$. de Casteluão, encarregado de uma comissão na na América do Sul. Goiás, 22 de outubro de 1844. Revista do I.H.G.B., VII, abril, 1845.

76) CASTRO (ABEL SOARES DE). - Origem dos Institutos Juridicos de Goiás. São Paulo. 1946.

77) CAStro (DERVAl Alves DE). - Anais da Comarca das Rio das Pedras - São Paulo, 1933. Valor muito pequeno. 
78) CASTRO (FELICIANO FERNANDES DE). - Monografia Histórica de Caiapônia. 1945.

79) CASTRO (JOÃO ALVES DE). - Mensagem. - 1921. Informaç̃̃es Oficiais.

80) CASTRO (QUINTINO DE). - Natividade e seus Municípios. 1950.

81). - CELSO (CONDE DE AFONSO). - Direitos de Goiás no Litígio Contra o Mato Grosso. Imprensa Oficial. - Rio de Janeiro, 1921.

82) COELHO (QUILHERME FERREIRA). - Expedição Histórica nos Sertóes de Goiás. 1937. Relatório de uma viagem ao Norte.

83) COLEÇÃO DE MAPAS DA CARTOGRAFIA PAULISTA ANTIGA. 7 vols., São Paulo, 1922.

84) CORDEIRO (HEITOR). - Contribuiçăo ao Estudo da Cultura do Trigo em Goiás. Rio de Janeiro, 1937. Obra técnica, que contém um pequeno Histórico da Cultura de Trigo em Goiás.

85) CORDOVIL (BARTOLOMEU ANTÔNIO). - Memórias. Americano diz que não existe mais.

86) COSTA (GERSON DE CASTRO). - Goiânia, a Metrópole do Oeste. Obra premiada em Concurso, não contém, entretanto, grande coisa.

87) COSTA (ODORICO). - A Descoberta das Minas da Goiás. In revista "Oeste", ano'III, n⿳ 18 - 1944.

88) COSTA (ODORICO). - A Deposição do Marenhal de Campo. In revista "Oeste", ano III, n' $19-1944$.

89) COSTA (ODORICO). - General Joaquim Xavier Curado. in revista "Oeste", ano III, n? $19-1944$.

90) COSTA (ODORICO). - Minas do Cocal. - In revista "Oeste". Ano I, $\mathrm{n}^{9} 1-1942$. Como todos os antigos dêste autor, todos publicados na revista Oeste, há pouca referência à bibliografia, entretanto, fornecem informação valiosa.

91) COSTA (ODORICO). - Um mês de fevereiro da História de Goiás. In. revista "Oeste". Ano I no 2, 1943.

92) COSTA (ODORICO). - Nos Albores da Formação de Goiás. In revista "Oeste", ano II, n' $5-1943$.

93) COSTA (ODORICO). - Na éra do Desbravamento de Goiás. In revista "Oeste", ano II, n' 6 - 1943.

94) COSTA (ODORICO). - Padre José Caitano Lobo Ferreira. In revista "Oeste", ano II, n' $7-1943$.

95) COSTA (ODORICO). - Fatos da História de Goiás. In revista "Oeste", ano II, $\mathrm{n}^{\circ} 8-1943$.

96) COSTA (ODORICO). - Igreja Matriz de Nossa Senhora Santana de Goiás. In revista "Oeste", ano II, n' $11-1943$. 
97) COSTA (ODORICO). - Os Jesuitas em Goiás. In revista "Oeste", ano III, n' $12-1944$.

98) COSTA (ODORICO). - Tragédias do Desbravamento. In revista "Oeste", ano III, $\mathrm{n}^{9} 13-1944$.

99) COSTA (ODORICO). - A Escravidão Nas Minas de Goiás. In revista "Oeste", ano III, n" $16-1944$.

100) COSTA (ODORICO). - Em época em que se descobriram as Minas de Goiás. In revista "Oeste", ano III, n' $17-1944$.

101) COSTA (ODORICO). - A Escravidão nas Minas de Goiás. In revista "Oeste", no $16-1944$.

102) COSTA (WALDIR LUIS). - Araxá, da Maloca ao Palácio. - Rio de Janeiro, 1950.

103) COUDREAU (HENRI). - Viagem ao Tocantins-Araguaia. Paris, 1897.

104) COUTINHO (J. J. DA CUNHA AZEREDO). - Obras Econômicas de J. J. da Cunha Azeredo Coutinho. São Paulo, 1966. Alguma referência.

105) COUTO (GOIÂS DO). - Memórias e Belezas da cidade de Goiás. 1958. Conferência Realizada perante a Assembléia Legislativa.

106) COUTO (LUUís RAMOS DE OLIVEIRA). - Viagem ao Norte de Goiás. 1910.

107) COUTO (LUfS RAMOS DE OLIVEIRA). - Goianos do meu tempo. Inédito. Desta obra, não se conhecem os originais.

108) COUTO (LUIS RAMOS DE OLIVEIRA). - Páginas de História de Goiás. Inédito. Desta obra não conhecem os originais.

109) CRULS (LUIS). - Relatório da Comissão Exploradora do Planalto Central do Brasil. São Paulo, 1947. Extremamente valioso, pela formação técnica dos membros da Expedição.

110) CURAdo (AGNELO ARLINGTON FleURY). - Fleurys e Curados. 1956. Obra de Caráter Genealógico.

111) CURAdo (S. FleURY). - Três Memórias Históricas. São Paulo 1938. São de algum valor.

112) CURAdo (SEBASTIÃO FLEURY), - Memórias Históricas. 1956. Alguns estudos têm valor.

113) DALTRO (ELOLINDA). - Da catequese dos Índios do Brasil. Rio de Janeiro, 1920.

114) DEFFONTAINE (PIERRE). - As Feiras de Burros de Sorocaba. Geografia $n^{\circ} 3$ - São Paulo, 1935. Pode conter referências à interligação do Comércio no Pcríodo Colonial, e mesmo em época mais próximas. 
115) “DESCONHECIDO.

Informação sôbre as Minas do Brasil. Anais da Biblioteca Nacional Vol. 57. 1939.

116) DESCONHECIDO.

Estradas Primitivas de Uberaba. VI, 93.

117) DESCONHECIDO.

Da Bahia Cabrália ao Planalto Central da República. Projeto: (Estrada de Ferro de Jequitinhonha). Rio de Janeiro, 1895.

118) DESCONHECIDO.

Roteieiro do Maranhãa a Goiás pela Capitania do Piaui. Revista I.H.G.B. - parte 1, 1900.

119) DESCCONHECIDO.

Um Almanaque de Formas. O exemplar que tenho por emepréstimo, do Prof. Modesto Gomes, está sem as primeiras e últimas páginas, não permitindo saber-se o Nome da obra e do autor. Possui informações valiosas.

120) DESGENETTES (RAIMUNDO HENRIQUES). - Os Índios Caiapós. Revista do I.H.G.B. 67, parte II, 1906.

121) DIAS (CARLOS MALHEIROS) (Direção de). - História da Colonização Portuguêsa no Brasil. Pôrto, 1921-1924.

122) DIVERSOS.

Anuário do Tocantins - Pium, 1957.

123) DIVERSOS.

Documentos oficiais' $n^{9} 1$ e 2 págs. 221 e seguintes. Tomo VII da Revista do I.H.G.B.

124) DIVERSOS.

Limites entre os Estados de Goiás e Minas Gerais, 1924.

125) DIVERSOS.

Goiás, Uma Nova Fronteira.Humana Vários Estudos Sôbre Goiás. Alguns têm valor.

126) DOMINICANOS MISSIONÁRIOS. Os Nossos Indios Caiapós e Carajás. Órgão da Catequese dos fndios na Prelazia de Conceição do Araguai e da Prelatura de Pôrto Nacional Rcv. $n^{\circ}$ 1, Poços de Caldas, 1922.

127) DOURADO (JOSÉ B. DA SILVA). - A Justiça de Arraias (1918-1944).

128) EHRENREICH (PAUL). - Contribuições para a Etnologia do Brasil. Revista do Museu Paulista. Nova Série, II - 1948. Desceu de vapor, o Araguaia (Leopoldina a Santa Maria).

129) EHRENREICH (PAUL). - Materialen zur Spra chenkunde Brasiliens. I Die Sprache der Karaya (Goiás) Zcitsehrift fur Ethnologie. Berlim, 26, 1894 - II Die Sprache der Caiapó (Goiás) Idem - III Die Sprache der 
Akua oder Chavantes und Cherentes (Goiás). Ibidem, 27, Berlim, 1895. Descreve também uma viagem pelos rios Araguaia e Tocantins, 1888-1889.

130) EHRENREICH (PAUL). - Sudamerikanische Stronfahrten Globus 62, Braunechweig, 1892 .

131) ELLIS JR. (ALFREDO). - o Bandeirismo Paulista e o Recuo do Meridiano. Brasiliana. 1938.

132) ELLIS JR. (ALFREDO). - O Ouro e a Paulistânia. Faculdade de Fi'osofia da Universidade de São Paulo - 1948.

133) ElliS JR. (ALFREDO). - Meio Século de Band:irismo. São Paulo. 1948.

134) ESCHWEGE (W. L. Von). - Pluto Brasiliensis. Brasiliana - vol. 257.

135) FERNANDES (PE. ANTÔNIO P. C.). - Missionário Jesuitas no Tempo do Marquês de Pombal.

136) FERREIRA (MANOEL RODRIGUES). - Nos Sertóes do Lendário Rio das Mortes. Editôra do Brasil S/A.

137) FLORENCE (HÊRCULES). - Viagem Fluvial do Tietê ao Amazonas, de 1825 a 1829. Talvez contenha informes sôbre Goiás à época.

138) FONSECA (JOSÉ PINTO). - Outra carta do mesmo autor. Revista do I.H.G.B., tomo 84, Rio de Janeiro, 1918.

139) FONSECA (JOSÉ PINTO DA). - Cópia da Carta que o Alferes José Pinto da Fonseca escreveu ao Esm. General de Goiases, dando-lhe conta do descobrimento de duas nações de indios, dirigida do sitio onde portou (1775), Revista do I.H.G.B., VIII (1846) 2a. Edição - Rio de Janeiro, 1867.

140) FRANÇA (BASILEU TOLEDO). - o Sudoeste - Tentativa de Interpretação. 1959.

141) FRANÇA (BASILEU TOLEDO). - Pioneiros - 1954.

142) FRANÇA (BASILEU TOLEDO). - Música e Maestros.

143) FRANCO (AFONSO ARINOS DE MELO). Sintese de História Econômica do Brasil. Rio de Janeiro, 1938.

144) FRANCO (FRANCISCO DE ASSIS CARVALHO). - Bandeiras e Bandeirantes. Brasiliana, 1940.

145) FRANCO (VIRGILIO DE MELLO). - Viagem a Goiás - 1882.

146) FRANCO (VIRGILIO DE MELLO). - Limites entre Minas e Goiás. VI, 539.

147) FREIRE (JOSÉ RODRIGUES). - Relação da Conquista do Gentio Xavante, Conseguida pelo ilm. e Exm. sr. Tristäo Cunha Menezes, Governador e Capitão General da Capiatnia de Goiás. Coleção Textos e Documentos 1, São Paulo - 1951. 
148) Frota (J. M. ANTUNES DA). - História da Capitania de Goiás. o Patriota - t. $3^{\circ}$ n. 2 - 1814. Publicado em "O Popular".

149) FURTADO (CELSO). - Formação Econômica do Brasil. Rio de Janeiro, 1959. Para consultas e ampliação de compreensão do quadro geral.

150) Gallais (ESTEVÃO M.). - Uma Catequese Entre os indios do Araguaia (1901). São Paulo, 1903.

151) GALLAIS (ESTỄ̃o MARIA O. P.). - o Apóstolo do Araguai - Frei Gil Vilanova. 1942. Biografia.

152) GARDNER (GEORGE). - Viagens ao Interior do Brasil. Brasiliana, 223, 1942.

153) GLASS (FREDERECK C.). - Adventures with the Bible Brazil. London, 1919.

154) GODOY (GARCIA). - Rio do Sono.

155) GOMES (HORIESTE). - Geografia de Goiás. É o único livro que conheço sôbre o assunto. Livro utilizável, bem entendido. $\mathrm{O}$ volume publicado contém "as bases físicas".

156) GOMES (VICENTE FERREIRA). - Itinerário da cidade de Palma em Goiás, à cidade de Belém do Pará, pelo rio Tocantins, e breve noticia do. do norte da Provincia de Goiás. Revista do I.H.G.B., 25, 1862.

157) GOULART (JOSÉ ALfPIO). - Tropas e Tropeiros na Formą̧ão do Brasil. Rio de Janeiro, 1961. É, segundo sei, o único estudo sôbre o assunto, que interessa profundamente a quem quiser estudar a formação histórica de Goiás.

158) GUIMARÃES (JOSÉ DA SILVA). - Memória sôbre os usos, costumes e linguagem dos Apiacás e descobrimento de novas minas na Provincia do Mato Grosso. Revista do I.H.G.B. - VI (1844). Ao Fim da memória, seguem-se alguns capítulos sôbre Goiás.

159) GUIMARÃES (JOSE SEABRA). - Notícia Estatistico - Descritiva do Municipio de Rio Veerde. Imprensa Oficial. 1941.

160) HANDELMANN (HENRIQUE). - História do Brasil. Revista do I. H.G.B., 1931.

161) HAULES (JAMES). - Estudos das Linhas Férreas e da Navegą̧ão das Bacias de São Francisco e do Tocantins (1823). Citado por Zoroastro.

162) HERNDL (CARLOS). - Relatório. Rio de Janeiro, 1921.

163) HOLANDA (SÉRgIO BUARQUE DE). -- Monções. Rio de Janeiro, 1941.

164) HOLANDA (SÉRGIO BUARQUE DE). - Caminhos e Fronteiras, Rio de Jaeniro, 1957. 
165) HOLANDA (SÉRGIO BUARQUE DE). - Expansão Paulista em fins do Século XVI e principios do século XVIII. São Paulo, Faculdade de Ciências Econômicas, 1948.

166). HOLANDA (SÊRGIO BUARQUE DE) (coordenação de). - História Geral da Civilização Brasileira. É de valor para consultas e relacionamento com tôda 'História do Brasil.

167) HOLANDA (SÉRGIO BUARQUE DE). - Indios e Mamelucos na Expansão Paulista. Anais do Museu Paulista. 1949.

168) FLORESTAN (FERNANDES). -

169) JACINTO (OLfMPIO). - Esbôço Histórico de Formosa. 1931.

170) JAGUARIBE (DR. DOMINGOS). - Mudança da Capital Federal do Brasil. São Paulo. 1896.

171) JARDIM (E. J. MORAES). - Linha Férrea e Fluvial do Tocantins $e$ Araguaia. 1880. Citado por Zoroastro.

172) JARDIM (E. J. MORAES). - Na vegação Interior do Brasil. Citação de Zoroastro. Rio de Janeiro, 1869.

173) JARDIM (JOAQUIM RODRIGUES DE MORAES). - O Rio Araguaia. Relatório de sua exploração pelo Major d'engenheiros Joaquim Rodrigues de Moraes Jardim, precedido de um resumo histórico de sua navegação pelo tenente coronel d'engenheiros Jerônimo Rodrigues de Moraes Jardim e seguido de um estudo sôbre os índios que habitam suas marges, pelo dr. Aristides de Souza Spinola, presidente de Goiás. Rio de Janeiro, 1880.

174) JAYME (JARBAS). - O Campo de Fôrça. In revista "Oeste", ano III, $\mathrm{n}^{\circ} 18,1944$.

175) JAYME (JARBAS). - Cinco Vultos Meiapontenses.

176) JAYME (JARBAS). - Do Passado ao Presente (Ensaios Genealógicos). Goiânia. 1952.

177) JUBÉ (ALCIDES CELSO RAMOS). - Ensaios de Corografia de Goiás. Goiás. 1919.

178) KRAUZE (FRITZ). - Sôbre o Araguaia. Citação de Zoroastro.

179) KRAUZE (HERMANN). - Goiás, das wahre herz brasiliens. São Paulo. 1936.

180) LACERda (AUgUSTO DE ABREU). - Bacia do Rio das Mortes. Citado por Zoroastro.

181) LAGO (ANTÔNIO AFLORENCIO PEREIRA DO). - Relatório dos estudos da comissão Exploradora dos Rios Araguaia e Tocantins. Rio de Janeiro. 1876.

182) LANDUCCI (ITALO). - Cenas e Episódios da Coluna Prestes 1947.

183) LEAL (OSCAR). - Viagem às Terras Goianas. Lisboa. 1882. 
184) LEITE (SERAFIM). - Novas Cartas Jesuíticas. Brasiliana. 194. 1940.

185) LEITE (SERAFIM). - História da Companhia de Jesus no Brasil. Rio de Janeiro. 1938.

186) LEME (PEDRO TAQUES DE ALMEIDA PAES). - Nobiliarquia Paulistana. Revista do I.H.G.B., 32, 1869, 33, 1870, 34, 1871, 35, 1872.

187) LIMA (HEITOR FERREIRA). - Formação industrial do Brasil. Em especial, veja-se o capítulo sôbre casas de fundição.

188) LIMA (GUIMARÃES). - Catalão em Marcha.

189) LIMA (GUIMARÃES). - Goids, Libertado. 1947.

190) LIMA (LOURENÇO MOREIRA). - A Coluna Prestes (Marchas e Combates). 1945.

191) LIMA (LOURENÇO MOREIRA). - A Coluna Prestes. São Paulo. 1945. Como atravessou Goiás por duas vêzes, faz observações sôbre a vida da época.

192) LIMA (MIGUEL DA ROCHA). - Mensagem do Presidente do Estado de Goiás - 1926. Contém observaçōes preciosas sôbre a situação do Estado na época, pôsto que do ponto de vista estritamente oficial

193) LISBOA (ANTÔNIO LUf́S TAVARES). - Roteiro da Viagem que, descendo pelo Tocantins, mandou fazer o ilm. Governador da Capitania de Goiás, José Almeida e Vasconcelos. i774. In Luís Santos Vilhena, Cartas de Vilhena, II - Bahia, 1922.

194) LOBO (JOSÊ). - Ligeiras Notas Históricas da Cidade de Bela Vista. Ribeirão Prêto.

195) LOBO (JOSÉ). - Contribuição Histórica da Imprensa Goiana. Ingra. Goiânia. 1949.

196) LOFGREN (AXEL). - Reconhecimento Geológico nos Rios Tocantins e Araguaia. Rio de Janeiro, 1936.

197) LUís (WASHINGTON). - Na Capitania de São Vicente. São Paulo, 1956. Citações Ocasionais, pois o estudo b não vai até 1725 .

198) LUÍS (WASHINGTON). - Capitania de São Paulo, Govêrno de Rodrigo César de Meneses. São Paulo. 1938. Obra bem composta, sôbre o Govêrno durante o qual se descobriu as Minas de Goiás.

199) MACHADO (ALCÂNTARA). - Vida e Morte do Bandeirante. São Paulo, 1965. A melhor análise sôbre a vida Dos Bandeirantes. Citações eventuais a Goiás. Vale a pena de ser ler.

200) MACHADO (ANTÔNIO CÂNDIDO DA CRUZ). - X, 199.

201) MADRE DE DEUS (GASPAR). - Memórias para a História de Capitania de São Vicente, hoje chamada São Paulo: Martins, 1953. 
202) MAGAlHÃES (AgENOR COUTO DE). - Encantos do Oeste. Rio de Janeiro, 1945.

203) MAGALHÃES (BAŚ́llO). - Expansão Geográfica do Brasil Colonial. Brasiliana, 1935 .

204) MAGALHÃES (COUTO DE). - IX, 915 - III, 499.

205) MAGALHÃES (JOSÊ VIEIRA COUTO DE). - Relatório dos Negócios da Emprêsa de Navegação do Araguaia. Rio de Janeiro, 1871.

206) MAGAlHães (JOSÉ VIEIRA COUTO DE). - o Selvagem. São Paulo, 1935.

207) MAGALHÃES (JOSÉ VIEIRA COUTO DE). - Viagem ao Araguaia. Brasiliana. Além da descrição de biagem, contém análises interessantes sôbre a Província na época em que o autor esteve. Anote-se em particular arrazeado sôbre a necessidade de se mudar a capital.

208) MANUSCRITO DA S.E.N.S. - Pro memória de Minas de Ferro e das Minas de Goyazez de Villa Boa e a segunda de Salitre na Capitania da Bahia, também pertencente à Capitania de Minas Gerais.

209) MANUSCRITO DA SECRETARIA DE ESTADO DOS NEGÓCIOS ESTRANGEIROS. - Prospécto na Capitania de Goyaz no ano de 1803, em que tomou posse de secretário do Govêrno della o bacharel Manoel Joaquim da Silveira Félix.

210) MASCARENHAS (FRANCISCO DE ASSIS). - Carta escrita por $D$. Francisco de Assis Mascarenhas no dia em que deu posse do Govêrno da Capitania de Goiás a Fernando Delgado Freire de Castilho, seu sucessor. Revista do I.H.G.B. - 1843 (3a Edição - 1885).

211) MATTOS (RAYMUNDO JOSE DA CUNHA). - Repertório da Legislação Militar. Citado por Zoroastro.

212) MATTOS (RAYMUNDO JOSÉ CUNHA DE). - Itinerário do Rio de Janeiro ao Pará e Maranhão, pelas Provincias de Minas Gerais e Goiás. Rio de Janeiro. 1936.

213) MATTOS RAYMUNDO JOSÉ DA CUNHA). - Corografia Histórica da Provincia de Goiás. Revista do I.H.G.B., 37, 1, 1874. - 38, 1, 1875.

Com as obras de Aleneastre e Silva e Souza, compóe o triangulo Clássico das obras válidas do século XIX, sôbre Goiás.

214) MAWE (JOHN). - Viagem ao Interior do Brasil, principalmente aos Distritos de Ouro e dos Diamantes. Rio de Janeiro. 1944.

215) MELO (AFONSO DE TOLEDO BANDEIRA DE). - A Descoberta $e$ a Exploração das Minas no Brasil. Sua influência no povoamento e nas comunicações. Revista do I.H.G.B., III, 1939, Assembléia Inalgural do I Panamericano de Geografia e História. 
216) MOACIR (PRIMITIVO). - A Instrução e o Império. 3 Vols. São Paulo, 1936-1938.

217) MOACIR (PRIMITIVO). - A Instrução $e$ as Províncias. 3 Vols. São Paulo, 1939-1940.

218) MONTEIRO (OFÉlIA SÓCRATES DO NASCIMENTO). - Corografia de Goiás. - I.H.G.B., - 1942.

219) MONTEIRO (OFÉlIA SÓCRATES DO NASCIMENTO). - Coro Nasceu Goiânia. 1938.

220) MONTEIRO (OFÉlIA SóCRATES DO NASCIMENTO). - Goiás, coração do Brasil. Goiás, 1933. Livro escrito para cursos pridário, que entretanto tec informações interessantes, inclusive a descrição de modo como se fazia uma viagem de Goiás a São Paulo à época.

221) MOOG (VIANNA). - Bandeirantes e Pioneiros. (paralelo entre duas culturas). Editôra Civilização Brasileira S/A. Rio de Janeiro, 1966.

222) MORAIS (EDUARDO JOSE DE). - Navegação Interior do Brasil. 1894.

223) MORAIS (JOSÉ DE). - História da Companhia de Jesus da extinta província do Maranhão e Pará. 1759. Rio de Janeiro. 1860.

224) MORAIS (JOÃO CORREIA DE). - Assuntos de Navegação (1886). Citado por Zoroastro.

225) MOURA (GENTIL DE ASSIS). - As Bandeiras Paulistas. Estabelecimentos das diretrizes gerais e que obedeceram o estudo das zonas que alcançaram. São Paulo, 1914.

226) MOURA (INÁCIO B. DE). - De Belém a São João do Araguaia (1868). Citado por Zoroastro.

227) MORÃO (MANOEL JOAQUIM DE AGUIAR). - Memória Estatistica. Americano diz que não existe mais.

228) NEIVA (ANTÔNIO TEODORO DA SILVA). - Um Estudo Antropológico: A formação e Cultura de Goiás. In "Mimesis", 1, 1965. Talvez o único estudo realizado e publicado sôbre o assunto, por estudioso radicado em Goiás. Há outros estudos, Zoroastro, por exemplo mas sem valor.

229) NEIVA (ANTÔNIO THEODORO DA SILVA). - Antropologia Cultural de Goiás. Inédito.

230) NEIVA (ARTHUR). - Evolução Econômica do Brasil.

231) NORMANO (J. F.). -Com - São Paulo, 1945.

232) ODEBRETCH (ADOLFO). - Exploração do Alto Tocantins e do $M a$ ranhão. (1920). Citado por Zoroastro.

233) OLIVEIRA (AMÉRICO LEONILdES BARBOSA DE). - o Vale Tocantins Araguaia. Possibilidades econômicas. Navegação Fluvial. Rio de Ja- 
neiro. 1941. Deve ter citações sôbre os locais por onde viajou, sua situação, população costumes na época.

234) OLIVEIRA (Dr. JOSÉ GONÇALVES DE). - Traçado das Estradas de Ferro do Brasil pelo Dr. José Gonçalves de Oliveira. 1892.

235) OLIVEIRA (EDNER COSTA E.). - O que Eu Vi nos Sertões de Goiás. 1950.

236) OLIVEIRA (HAROLDO CÂNDIDO DE). - Indios e Sertanejos do Araguaia. São Paulo, 1950.

237) OLIVEIRA (JOSÉ MANOEL D ASILVA). - Descrição do estado atual da navegação nos rios Araguaia e Tocantins e Maranhão, dirigida em 1808 ao Ex. Sr. D. Rodrigo Souza Coutinho, por José Manoel da Silva Oliveira.

238) OLIVEIRA (MACHADO DE). - Os Caiapós, sua origem, descobrimento, etc. Rev. do I.H.G.B., 24, 1861.

239) OLIVEIRA (SILVA E.). - Geografia e Geologia do Ouro (1808). Citado por Zoroastro.

240) PARANAgUÁ (Dr. J. NOGUEIRA): - Do Rio de Janeiro ao Piaú. 1905.

241) PATERNOSTRO (JÚLIO). - Viagem ao Tocantins. Brasiliana, 248, 1945.

242) PEIXOTO (EDUARDO MARQUES). - Os Descaminhos do Ouro. Revista do I.H.G.B., 72, II, 167.

243) PEIXOTO (FRANCISCO SIZENANDO). - Explorą̧ão do Rio Araguaia. (1868). "O Arquivo", ano I, Vol. 2, Cuiabá, 1905.

244) PIMENTEL (ANTÔNIO MARTINS DE AZEVEDO). - O Brasil Central 'estudos Patryes'. Revista do I.H.G.B. Tomo 68 - parte II - 1907.

245) PINTO (ALFREDO MOREIRA). - Apontamentos, para o Dicionário Geográfico do Brasil. I - Rio de Janeiro, 1894. II - Rio de Janeiro, 1896, III - Rio de Janeiro, 1899. Dados Interesantes sôbre população.

246) PINTO (OLEGÁRIO). - Interêsse de Goiás. Discursos. 1925.

247) PINTO (OLEGÃRIO HERCULANO DA SILVA). - o Restabelecimento da Navegação do Araguaia. Imprensa Oficial. Rio de Janeiro, 1923.

248) PIRES (HELIODORO). - A Paisagem Espiritual do Brasil do Século XVIII. São Paulo. 1937.

249) PIRES (HELIODORO). - Temas de História Eclesiástica do Brasil. São Paulo. 1946.

250) 'POHL (J. E.).' - Viagem ao Interior do Brasil. Instituto Nacional do Livro. 1951 .

251) POMBO (ROCHA). - História do Brasil. Referências ocasionais a Goiás.

252) PÔRTO SEGURO (VISCONDE DE). - A Questão da Capital: Marítima ou Interior? Memorial Orgânico Pelo Visconde de Pôrto Seguro. Viena, 1877. 
253) PRADO (J. F. DE ALMEIDA). - A Bahia e as Capitanias do Centro do Brasil. Brasilianas Sôbre a penetração leste oeste, é útil.

254) PRADO JR. (CAIO). - Formą̧ão do Brasil Contemporâneo (Para Orientação).

255) PRADO JR. (CAIO). - História Econômica do Brasil. (Para orientação).

256) PRIMÉRIO (FIDELIS M. DE). - Capuchinhos em Terra de Santa Cruz. São Paulo, 1942.

257) QèINTA (WALDIR DE CASTRO). - Letras e Literatos. In Catálogo Bibliográfico de Goiás. Goiânia, 1966.

258) RAMOS (ARTUR). - Introdução à Antropologia Brasileira. Edição Casa do Estudante. Valioso para estudos de Etnologia de Goiás.

259) RAMOS (VICTOR D ECARVALHO). - o Descobrimento de Goiás e seu Bi-Centenário.

261) RAPM. - Limites Minas-Goiás. XI, 429 - II, 372 - VI, 539 - IX, 795.

261) REAL (THOMAZ DE SOUZA VILLA). - Viagem de Thomaz de Souza Villa Real pelos Rios Araguaia, Tocantins e Vermelho (1792). Revista do I.H.G.B. 2a. série, IV (1848). Rio de Janeiro, 1891.

262) REGO (F. RAGAEL DE MELO). - Limites de Goiás com Mato-Grosso. Rio de Janeiro, 1897.

263) REGO (LUIS FLORES DE MORAIS). - Notas Geográficas Sôbre o Rio Tocantins. Boletim do Museu Goeli. Citado por Zoroastro.

264) REIS (ARTUR CÉSAR FERREIRA). - Panorama Histórico do Brasil Central. Rio de Janeiro, 1949. Este Estudo, publicado em "Goiás", uma Nova Fronteira Humana, pode ser utilizado. Entretanto é um pouco resumido, melhor é a contribuição ao autor à História Geral da Civilização Brasileira, sôbre História de Goiás.

265) REIS (GELMIRES). - Principais Efeméridades da História de Goias até 1929 .

266) REIS (GELMIRES). - Almanaque de Santa Luzia. Uberaba, 1925.

267) REIS (GELMIRES). - Genealogia Luziana, 1929.

268) REIS (VASCO DOS). - Pelo Estado Nôvo. - Inútil.

269) RIBEIRO (FRANCISCO DE PAULA). - Roteiro que fez o Capitão Francisco de Paula Ribeiro à Fronteira da Capitania do Maranhão e da de Goiás, no ano de 1815. Revista do I.H.G.B., X (1848) - 2a. Ed. 1870.

270) RIBEIRO (JOÃ) . - História do Brasil. Referências várias e úteis, sôbre Goiás.

271) RIBEIRO (JOAQUIM). - Folclore dos Bandeirantes. Rio de Janeiro. 1946. 
272) RIBEYROLES (CHARLES). - Brasil Pitoresco. História. Descrição. Viagens. - Colonização - Instituição. - São Paulo, 1941.

273) RICARDO (CASSIANO). - Marcha Para o Oeste. Documentos Brasileiros.

274) RIVET (PAUL). - Os Índios Canoeiros. Jornal de la Societé dos Americanistes, Paris. 1924.

275) RODRIGUES (LYSIAS). - O Rio dos Tocantins. - I.H.G.B., 1945.

276) RODRIGUES (LYSIAS). - Roteiro do Tocantins. Rio de Janeiro. 1943.

277) RUGENDAS (JEAN MAURICE). - Viagem Pitoresca Através do Brasil. Além de desenhos de Goiás e habitantes, deve ter referências, procurar.

278) S; (J. NORBERTO DE). - Damiana da Cunha. Revista do I.H.G.B., XXIV, 1861.

279) SAINT-ADOLPHE ( J. C. R. MILLIET DE). - Dicionário Geográfico, Histórico do Descritivo do Império do Brasil. Paris. 1845. Valiosa referências sôbre a população de Goiás, e outros dados.

280) SAINT-HILAIRE. - Viagem às nascentes do Rio São Francisco e Provincia de Goiás. Companhia Editôra Nacional, 1937. Valiosa pela confiança que o autor merece. Traz informações sôbre à vida da época.

281) SANTANA (MOISÉS). - Vultos e Fatos de Goiás. Goiás. 1927.

282) SANTOS (AMILCAR SALGADO DOS). - Cartas de Goiás. 1937.

283) SANTOS (OMAR). - No Limite da História Goiana. In revista "Oeste", ano II, $\mathrm{n}^{\circ} 4.1943$.

284) SARINHO. - Navegação do Araguaia e Tocantins. 1887. Citado por Zoroastro.

285) Segurado (JOAquim TeOtônIo). - Memória. Americano cita a obra, dizendo que os originais desapareceram.

286) SEgURAdo (RUfino teOtôNIO). - Viagem de Goiás ao Pará. Revista do I.H.G.B., X (1848) - 2a. Ed. 1870.

287) SHEARER (H. K.), SOUZA (HENRIQUE) e CAPPER (A. DE). Araguaia - Recursos Minerais. Rio de Janeiro. 1944. copyright by prof. S.P.M.

288) SEIXAS (JOSÉ CORREIA). - Memórias (1785). Americano cita a obra, dizendo que os originais desapareceram.

289) SILVA (COLEMAR NATAL E). - História de Goiás. Rio de Janeiro. 1935: Obra de valor relativo, as transcriçōes de Documentos que contém valorizam-na bàsicamente, o autor se utilizou apenas de dois livros: Alencastre e Silva e Souza. Cita Cunha Mattos ocasionalmente. Quem possuir exemplares das obras citadas, pode dispensar esta.

290) SILVA (CÔNEGO JOSÉ TRINDADE DA FONSECA E). - Jesuita de Goiás. In revista "Oeste", ano III, n ${ }^{0} 23,1944$. Capítulo de livro inédito. 
291) SILVA (CÔNEGo JOSÉ TRINDADE DA FONSECA E). - Centenário do Liceu de Goiás. In "Revista de Educação e Saúde". No 25-26, 1946.

292) SILVA (EURIDICE NATAL E). - Notas de Viagem ao Araguaia. Goiânia. 1939.

293) SILVA (EURIDICE NATAL E). - Traço Biográfico de Guimarães Natal. Goiânia, 1937 .

294) SIlVA (DE CASTRo E). - Êsse colosso, o Brasil. São Paulo. 1941.

295) SIlva (HENRIQUE). - Sumé e o Destino da Nação Goiás. Rio de Janeiro. 1910.

296) SILVA (HENRIQUE). - Coletânea de Mapas Coloniais.

297) SILVA (HENRIQUE). - A Bandeira de Anhanguera a Goiás em 1722. Niterói, 1917. O Grande pesquisador das coisas de Goiás, fixa o que acredita ser o roteiro real da Bandeira de Anhanguera, transcrevendo os roteiros de Silva Braga e Urbano do Couto.

298) SILVA (HENRIQUE). - Esbộ̧o Biográfico do Comendador Francisco José da Silva. Rio de Janeiro. 1907. Esta pequena Biografia familiar, traz muita relação sôbre a vida e costumes no século XIX.

299) SILVA (HENRIQUE). - A Tribo Goiá. Congresso internacional de Americanistas. XVIII a. sessão, Londres, 1912. I, Londres. 1913.

300) SILVA (HENRIQUE) (e outros). - Memória descritiva dos limites do Goiás com os Estados de Mato Grosso, Minas Gerais, Pará e Bahia. Rio de Janeiro. 1920. Extremamente bem elaborada, não apenas tem valor por si mesma, como transcreve inúmeros documentos que dizem respeito às fronteiras de Goiás.

301) SILVA (HERMANO RIBEIRO DA). - Nos sertões do Araguaia. São Paulo. 1935.

302) SILVA (INÁCIO XAVIER DA). - De Goiás Velha a de Cuiabá. Goiânia, 1950.

303) SILVA (INÁCIO XAVIER DA). - O Crime do Coronel Leitão. 1935.

304) SILVA (JOÃo CAETANO DA). - Digressão que fêz João Caetano da Silva, natural de Meia Ponte, em 1817, para descobrir, como com efeito descobriu, a nova navegação entre as Capitanias de Goiás e a De São Paulo, pelo Rio dos Bois, até o Rio Grande que divide as duas Capitanias; cuja navegação tinha sido tentada pelo Exm. Sr. Conde da Palma, quando foi Governador da Capitania de Goiás, mas cuja tentativa não teve efeito por ser ter perdido a expedição. Revista do I.H.G.B., II, 312, 1840.

305) SILVA (MODESTO GOMES DA). - Quatro faces dos Vilarejos Goianos. In "Mimesis", 1, 1965. Este trabalho pode ser tido como continuação de outros, do mesmo autor, publicado no "Cadernos de Estudos Brasileiros", 1, 1963, sob o título de "Os Turbulentes Arraias Goiânos". Talvez seja o 
primeiro autor a realizar uma análise realmente histórica dos aglomerados urbanos goianos.

306) SILVA (VICENTE AIRES DA). - Roteiro feito pelo Tenente Coronel Vicente Aires da Silva, da Exploração por êle feito pelo Rio do Sono, acima; entregou ao I.H.G.B., em 26 de setembro de 1851, por Antônio de Pádua Fleury.

307) SILVEIRA (ALVARO A. DA). - Viagem pelo Brasil. 1907.

308) SILVEIRA (JOSE PEIXOTO DA). - A Nova Capital.

309) SIMONSEN (ROBERTO). - História Econômica do Brasil. Brasiliana. Referências esparsas, a cerca da produção aurifera e outros tipos de produção em Goiás.

310) SIQUEIRA (JALES MACHADO DE). - Quinze anos de Ditadura. Rio de Janeiro. 1949.

311) SIQUEIRA (JALES MACHADO DE). - Relatório (do secretário de Obras Públicas do Presidente do Estado, Alfredo Lopes de Morais).

312) SIQUEIRA (JOAQUIM BONIFACIO DE). - A Descoberta de Goiás. 1921.

313) SIQUEIRA (JOAQUIM BONIFÁCIO DE). - Esboço Geneológico da Familia Siqueira. 1921.

314) SIQUEIRA (JOSÉ ASSUERO DE). -Pequena Corografia de Goiás. Imprensa Metodista, 1942.

315) SIQUEIRA (REV. PE. JOSE MANOEL DE). - Memória a respeito do descobrimento dos Martírios pelo Rev. José Manoel de Siqueira:" "Revista da Sociedade de Geografia do Rio de Janeiro". Tomo II, 1886.

316) SOUTHEY (ROBERT). - História do Brasil. Salvador, 1949. Referências esparsas.

317) SOUSA (BERNARDINO JOSÉ DE). - O Ciclo do Carro de Boi ño Brasil. Brasiliana. Util para completar estudos.

318) SOUZA (LUIZ ANTôNIO DA SILVA E). - Memórias Estatísticas da Provincia de Goiás. Citado por Americano o qual diz que os originais desapareceram. Seria a mesma dos Anais?

319) 319) SOUZA (LUIZ ANTÔNIO DA SILVA E). - Elenco de Província de Goiás. Citado por Zoroastro.

320) SOUZA (LUIZ ANTÔNIO DA SILVA E). - Citado por Zoroastro (?)

321) SOUZA (LUIZ ANTÔNIO DA SILVA E). - Memória sôbre o Descobrimento, Govêrno, População e Coisas Mais Notáveis da Província de Goiás. Revista do I.H.G.B., $4^{\circ}$ trimsetre, 1849. Obra valiosa, pôsto que descritiva e resumida, como o próprio autor admite foi muito curto o tempo que têve para pesquisar. 
322) SOUZA (LUÍS DE VASCONCELOS E). - Negócios Eclesiásticos no Brasil Colonial (1783). Revista do I.H.G.B., 51, II, 97.

323) SOUZA (LUÍS DE VASCONCELOS E). -

324) SPIX E MARTIUS. - Viagem pelo Brasil.

325) STEINEN (KARL VON DEN). - Entre os aborigenes do Brasil Central. São Paulo, 1940. Deve haver edição posteriore.

326) STEINEN (KARL VON DEN). - O Brasil Central. São Paulo, 1942.

327) "SUDOESTE". - Bibliografia Contida no Sudoeste de Basilen. - PG. 47 e seguintes.

328) SILVA (CÔNEGo JOSÉ TRINDADE DA FONSECA E). - Lugares $e$ Pessoas.

329) TAQUES (PEDRO). - Notícias das Minas de São Paulo e dos sertões da mesma Całitania. São Paulo, 1954.

330) TAUNAY. - Inocência.

331) TAUnAY (A. E.). - Ensáios da Carta Geral das Bandeiras Paulistas. São Paulo, 1952.

332) TAUNAY (A. E.).- História Geral das Bandeiras Paulistas. São as descrições sistematizadas mais completas que temos por enquanto.

333) TAUNAY (A. E.) (INTRODUÇÃo E NOTAS DE). - Relatos Sertanistas - Coletânia. Biblioteca de História Paulista Martins, 1954.

334) TAUNAY (AFONSO DE). - Os Primeiros Anos de Goid́s. SO. 1950.

335) TAUnaY (ALFREDO DE). - A Provincia de Goiás, na Exposição Nacional de 1875.

336) TAUNAY (ALFREDO D'ESCRAGNOLLE). - Marchas das Fôrças. (1865-1866).

337) TAUNAY (ALFREDo D'ESCRAGNOLLE). - Goiás. Melhoramentos, 1931.

338) TAUNAY (VISCONDE DE). - Céus e Terras do Brasil. Rio de Janeiro. 1882 .

339) TEIXEIRA (JOSE A.). - Estudos de Dialetologia Portuguêsa. São Paulo. II, 1944.

340) TEIXEIRA (PEDRO LUDOVICO). - A Mudança da Capital de Goiảs. Goiânia, 1955.

341) TELES (GILBERTO MENDONÇA). - A Poesia em Goiás.

342) TELES (GILBERTO MENDONÇA). - Dicionário Toponimico de Goiás. Inédito. Há a transcrição de alguns trechos dessa obra em um número da revista de Educação.

343) TOURNIER (RR.). - Lá Longe, no Araguaia. 1942. 
344) TAVARES (CRISPIANO). - Contos Inéditos. Uberaba, 1910.

345) VARNHAGEM (FRANCISCO ADOLFO DE). - História Geral do Brasil. As citações e referências a Goiás são insignificantes, dado o volume da obra, Entretanto há algumas do interêsse.

346) VÁRIOS AUTORES. - Subsidios para a História da Capitania de Goiás. Revista do I.H.G.B., 84, (1918) - Rio de Janeiro. 1920.

347) VÁRIOS. - Tocantins: História, Navegą̧ão, Obstáculos e Cachoeiras.

348) VASCONCELOS (DIOGO DE). - História Antiga das Minas Gerais. Ouro Prêto, 1901.

349) VASCONCELOS (SALOMão DE). - Bandeirismo. Belo Horizonte. 1944.

350) VIANA (F. J. OLIVEIRA). - Evolução do Povo Brasileiro. In recenseamento Geral do Brasil, 1920. Contém dados e citações importantes para se conhecer a população de Goiás em diversas épocas. Em anexos, há reproduções interessantes de mapas, com variações de Fronteiras.

351) VIANA (URBINO). - Bandeiras e Sertanistas Baianos. São Paulo. 1935.

352) VIEIRA (ANTÔNIO). - Cartas de Pe. Antônio Vieira. Biblioteca de Escritores Portuguêses. Série e, I, Coimbra, 1925. Série e, II, Coimbra, 1926. Série e, III, Coimbra, 1928.

353) VIEIRA (PE. ANTÔNIO). - Cartas de Pe. Antônio Vieira. Tomo I, pág. 116 e seguintes, na edição de 1885 .

354) VIGGIANO (PEDRO). - Centenário do Liveu de Goiás. In "Revista de Educação e Saúde". No 27-28, 1946.

355) VIGgIANo (PEDRO). - Bartolomeu Bueno, Couto de Magalhães e Pedro Ludovico. In "Revista de Educação", 38, 1959. O Artigo é completamente prejudicado pela intenção de gloriar um chefe político.

356) VIGGIANO (PEDRO). - Navegação do Araguaia. In "Revista de Educação", 40, 1959. Algumas Citaçōes de autoridades que se empenharam para transformar em realidade a navegação pelo Araguaia.

357) VIGgIaNo (PEDRO). - Memória do Liceu Goiano. In "Revista de Educação", 37, 1959. Simples consideração a respeito da Fundação do Antigo Lyceo de Goyáz. Diz-se que foi transferido para Goiânia.

358) XAVIER (ÁLVARO JOSÉ) (manuscrito da S.E.N.E.). - Informação sôbre alguns pontos relativos à navegação e indios da Provincia de Goiás, dada em 1808 ao Ex. Sr. D. Rodrigo de Sousa Coutinho, por Alvaro José $X$ avier.

359) WAILBEL (LEO). - Uma Viagem de reconhecimento ao Sul de Goiás. I.H.G.B., 1949.

360) PALACIN (LUIS). - A Estrutura e a Conjuntura Numa Capitania de Minas. Inédito. Goiás, 1722-1822. 
361) JAIME (JARBAS). - Esbôço Histórico de Pirenópolis.

362) FERREIRA (MANOEL RODRIGUES). - O Mistério do Ouro dos Martirios. Edit. Biblos. São Paulo. 1960.

363) CAMPOS (ONALDO). - Rio Verde Histórico. São Paulo Edigraf. 1971. Aspectos históricos de Rio Verde (Goiás).

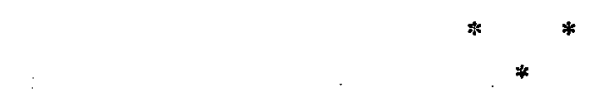

RESENHA DO SERVIÇO DE DOCUMENTAÇĀO DO ESTADO DE GOIÃS.

1. - Século XVIII.

Livro de registro da tesouraria - 1728 .

Livro de registro de protocolo - 1763-1822.

Livro de registro de cartas expedidas pclo govêrno - 1755 .

Livro de registro de cartas sôbre vários particulares - 1756 .

Livro de registro de conta corrente - 1769.

Cartas régias - instruçōes - 1799 - 1809 .

Portaria do govêrno - 1778 .

Balanço da receita - 1778-82.

Livro de rcgistro de cartas do govêrno - 1772 .

Livro de registro de oficios - 1744 .

Livro de registro de cartas do govêrno -1772 .

Livro de registro de oficios - 1744 .

Livro de registro de cartas régias - 1758.

Livro de registro de provisões - 1769-79.

Livro de registro de provisões - 1757-62.

Livro de registro da secretaria do govêrno - 1777 .

Livro de registro de ordens régias -1760 .

2. - Século XIX.

Livro de registro de oficios e portarias do govêrno - 1842-48.

Livro de registro de oficios dirigidos a câmara municipal - 1858-71.

Livro de registro da correspondência - juiz de direito - 1860-66 .

Livro de registro de correspondência militar $-1858-59$.

Livro de registro de oficios ao bispo $-1840-58$.

Livro de registro de oficios da policia militar - 1851-56.

Livro de resoluções e orçamento provinciais - 1838-40.

Livro de registro de correspondência oficial -1823 .

Livro de registro de oficios as capitais e aldeias - 1824-29.

Livro de registro de titulos e provisões - 1841-50.

Livro de registro de leis provinciais - 1837 .

Livro de registro das provisōes vigarios $-1859-72$. 
Livro de registro de conta corrente - 1839-40.

Livro de registro de provisões - 1858-72.

Livro de registro de correspondência c/govêrno - 1866-70.

Livro de registro de atas da presidência - 1869-72.

Livro de registro de correspondência do presidio - 1854-59.

Livro de registro de oficios aos administradores - 1868-69.

Livro de registro de decretos imperiais - 1885-94.

Livro de oficios reservados - 1880-83.

Livro de registro de comunicação de autoridade f $c$ ra provincia - 1858-73.

Livro de registro de correspondência do govêrno $\mathrm{c} \circ \mathrm{m} \mathrm{a} \mathrm{C}$. M. -1876 .

Livro de registro de ordens régias as províncias -1819 .

Livro de registro de instrução pública - 1871-73.

Livro de registro de comunicações de cobranças - 1862-73.

Livro de registro de decretos do império - 1870-85.

Livro de registro de circulares - 1872-84.

Livro de registro de provisões de vigários - 1873-89.

Livro de registro de oficios presidência - 1874-77.

Livro de registro de resumo de oficio da sec. fazenda - 1884-86.

Livro de registro das autoridades eclesiasticas estado Goiás - 1842-32.

Livro de registro de têrmos de juramentos - 1802-36.

Livro de registro de relação modernas do regimento - Henriques - 1823.

Livro de registro de oficios do govêrno - 1823-24.

Livro de registro de oficios a autoridades fora da província -1836 .

Livro de registro de ordem de pagamento - 1842-45.

Livro de registro de provisōes vigários - 1836-41.

Livro de registro de provisões do govêrno - 1877-83.

Livro de registro de atas do conselho da província de Goiás - 1824.

Livro de registro de ofícios da câmara municipal - 1848-53.

Livro de registro de ordem régias ao govêrno - 1820-23.

Livro de registro da coletoria de Vila Conceição - 1860-89.

Livro de registro de ofícios do secretário - 1828-35.

Livro de registro de patentes - 1862-75.

Livro de registro de ofícios a autoridades fora da província - 1853-58.

Livro de registro de atos do govêrno - 1876-79.

Livro de registro de correspondência da Província - 1880-83.

Livro de registro de correspondência dos magistrados - 1823-32.

Livro de registro de ordens régias - 1801-02 .

Livro de registro de correspondência da repartição de terra - 1858-60.

Livro de registro do correio $-1907-18$.

Livro de registro geral do govêrno - 1839-45.

Livro de registro geral do govêrno - 1835-39.

Livro de registro geral do govêrno - 1830-32.

Livro de registro geral do govêrno - 1828-30.

Livro de registro de ofícios do govêrno as autoridades policiais - 1878-83. 
Livro de registro geral do govêrno - 1804-28.

Livro de registro geral do govêrno - 1820-24 .

Livro de registro de minuta -1888 .

Livro de registro de decretodo do govêrno provincial - 1890 .

Livro de registro de pagamento dos empregados da província - 1863.

Livro de registro de diário da coletoria de Taguatinga -1895 .

Livro de registro de arquivamento de livros da S.E.N.I.I. -1800.

Livro de registro de recibo do correio - 1886-90.

Livro de registro de recibo do correio - 1890-93.

Livro de registro de recibo do correio - 1845-50.

Livro de registro de recibo do correio - 1879-80.

Livro de registro de cargas edescargas de artigos bélicos - 1836-61.

Livro de registro da tesouraria provincial - 1876-81 .

Livro de registro da tesouraria provincial - 1873-74.

Livro de registro da tesouraria provincial $-1875-7.6$.

Livro de registro da tesouraria provincial - 1874-75.

Livro de registro da tesouraria provincial $-1871-72$.

Livro de registro da tesouraria provincial - 1869-71.

Livro de registro de informaçōes e representações -1811 .

Livro de registro de comunicações ao ministério da justiça $-1858-62$.

Livro de registro de comunicações ao ministério da justiça - 1881-84.

Livro de registro de comunicações ao ministério da justiça - 1856-58.

Livro de registro de comunicaçōes ao ministério da justiça - 1873-76.

Livro de registro da tesouraria provincial reservados $-1871-74$.

Livro de registro da tesouraria geral da fazenda $-1873-74$.

Livro de registro da tesouraria geral da fazenda $-1873-88$.

Livro de protocolo da presidência - 1885-87.

Livro de registro da tesouraria geral da fazenda - 1872-73.

Livro de registro da tesouraria geral da fazenda - 1875-76.

Livro de registro da tesouraria geral da fazenda $-1874-75$.

Livro de protocolo da presidência - 1885-86.

Livro de registro da tesouraria geral da fazenda - 1883-84.

Livro de registro de despachos e ofícios - 1884-85.

Livro de registro de despachos e ofícios - 1883-84.

Livro de registro dos editais e proclamaçōes -1827 .

Livro de registro dos secretários - 1867-73.

Livro de registro das autoridades policiais - 1899-07.

Livro de regiśtro de matrícula dos delegados - 1899-1908.

Livro de registro de matrícula dos delegados - 166-86.

Livro de registro de matrícula dos sub-delegados - 1899-1908.

Livro de registro de matrícula dos delegados - 172-92.

Livro de registro de obras públicas - 1875-82.

Livro de registro da secretaria de finança - 1912-17.

Livro de registro de ofícios da presidência da província - 1888-89. 
Livro de registro de ofícios do govêrno - 1892-93.

Livro de rçistro da câmara municipal - 1882-90.

Livro de registro de protocolo de ofícios da presidência - 1887-88.

Livro de registro de têrmo declaração dos possuidor de terra -1811 .

Livro de registro de recibos do correio - 1880-83.

Livro de registro do protocolo da sec. do interior e justiça - 1901-04.

Livro de registro de diário de coletoria da capital - 1868-70.

Livro de registro de correspondência com a presidência - 1871-73.

Livro de registro da tesouraria provincial - 1878-80.

Livro de registro de correspondência presidencial -1873 .

Livro de registro de recibo do correio - 1854-58.

Livro de registro de ofícios ao presidente - 1824.

Livro de registro de guias e transporte -1821 .

Livro de registro de juiz municipal - 1847-56.

Livro de registro de juiz municipal - 1873-47.

Livro de registro de juiz municipal - 1833-37.

Livro de registro da tesouraria geral - 1864-66.

Livro de registro da tesouraria geral - 1861-64.

Livro de registro de juiz municipal - 1877-81.

Livro de registro da guerra -1867 .

Livro de registro de juiz municipal - 1873-75.

Livro de registro de juiz municipal - 1875-77.

Livro de registro de juiz municipal - 1856-62.

Livro de registro de juiz municipal $-1881-84$.

Livro de registro de protocolo - 1889-93.

Livro da porta - 1884-86.

Livro da porta - 1886-87.

Livro da porta $-1881-83$

Livro da porta $-1883-84$.

Livro da porta - 1888-89.

Livro da porta - 1887-88.

Livro de registro da Secretaria do govêrno correio - 1899-900.

Livro de registro de inspetores paroquais - 1873-79.

Livro de registro de ofícios da secretaria inspetoria - 1879-83.

Livro de registro de recibo de oficios do correio - 1874-76.

Livro de registro de recibo de oficios do correio - 1872-73.

Livro de registro do recibo de ofícios de correio - 1876-77.

Livro de registro de resumo de ofício da tesouraria - 1861-73.

Livro de registro de licença e demissão dos empregados - 1858-85.

Livro de registro de fôlha de pagamento de obras públicas - 1878-79.

Livro de registro de provisōes - 1820-22.

Livro de registro de provisões - 1821-29.

Livro de registro de ordem do govêrno - 1836 .

Livro de registro de ordem régias -1808 . 
Livro de registro de requerimento e despacho $-1817-21$.

Livro de registro de requerimento e despacho -- 1906-07.

Livro de registro da secretaria do govêrno - correio - 1870-71.

Livro de registro do roteiro da espedição - Rio dos Bois - 1874.

Livro de registro de regulamento exposto pelo govêrno - 1858-62.

Livro de registro de fôlha de pagamento - 1864 .

Livro de registro do secretário - 1851-57.

Livro de registro de portarias do govêrno $-1857-59$.

Livro de registro da presidência de Goiás - 1857-59.

Livro de registro de atos do govêrno - 1887 .

Livro de registro de ofícios ao secretário do reino - 1820-24.

Livro de registro de ofícios para a côrte - 1812-17.

Livro de registro de ofícios e portarias do govêrno - 1823-24.

Livro de registro de ofícios -1809 .

Livro de registro de correspondência geral $-1858-60$.

Livro de registro de documentos diversos -1823 .

Livro de registro de correspondência geral - 1881-83.

Livro de registro de correspondência do chefe de polícia $-1858-60$.

Livro de registro geral da secretaria da Fazenda - 1888.

Livro de registro de instrução pública -1880 .

Livro de registro da chefatura de policia - 1864-69.

Livro de registro da tesouraria de Goiás - 1883-85.

Livro de registro de correspondência c/os administ:adorss - 1883-86.

Livro de registro de patentes confirmadas - 1847-77.

Livro de registro de patentes confirmadas - 1824-46.

Livro de registro de patentes confirmadas - 1820-23.

Livro de registro da guarda nacional - 1832-42.

Livro de registro da guarda nacional - 1867-72.

Livro de registro da guarda nacional - 1859-62.

Livro de registro da guarda nacional $-1883-84$.

Livro de registro de informações - 1883-86.

Livro de registro de fôlha de pagamento $-1872-73$.

Livro de registro de informações - 1898-99.

Livro de registro de fôlha de pagamento - 1871-72.

Livro de registro de fôlha de pagamento $-1856-73$.

Livro de registro de fôlha de pagamento - 1872-73.

Livro de registro de informações - 1892-95.

Livro de registro do ministério da guerra - 1848-52.

Livro de registro do ministério da guarra - 1845-48.

Livro de registro do ministério da guarra - 1840-45.

Livro de registro do ministério da guerra - 1834-40.

Livro de registro do ministério da guerra - 1829-34.

Livro de registro do ministério da guerra - 1820-24.

Livro de registro do ministério da guerra - 1852-58. 
Livro de registro de informações e representaçôes -1803 .

Livro de registro de fôlha de pagamento de juros de apólices - 1889 .

Livro de registro de fôlha de pagamento - 1889.

Livro de registro de ponto - 1896-97.

Livro de registro da recebedoria de Rio Verde - 1856-86.

Livro de registro de ofícios - 1822-26.

Livro de registro de ofícios -1822 .

Livro de registro do conselho supremo $-1824-57$.

Livro de registro de correspondência - 1823-25.

Livro de registró da secretaria do govêrno - 1827-31.

Livro de registro da diretoria geral de estatística - 1872-74.

Livro de registro de obras públicas - 1863-74.

Livro de registro de informação - 1877-81.

Livro de registro de têrmos de juramento de estrangeiros - 1872-92.

Livro de registro de atos do govêrno - 1881-83.

Livro de registro de atos do govêrno - 1880-81.

Livro de registro de atos do govêrno - 1883-84.

Livro de registro de portarias - 1809-15.

Livro de registro de portarias - 1821 .

Livro de registro de conta corrente - 1858-61.

Livro de registro das rendas das coletorias -1838 .

Livro de registro de atos do govêrno - 1838 .

Livro de registro de correspondência - 1823-29.

Livro de registro de correspondências - 1838-34.

Livros de registro de ofícios $\mathrm{p} /$ comandante das armas -1830 .

Livro de registro de certidōes - 1823 .

Livro de registro de documentos militares - 1821 .

Livro de registro da guerra $-1843-49$.

Livro de registro de patentes - 1863-82 .

Livro de registro do diário da agência do forte -1822 .

Livro de registro de alvará -1775 .

Livro de registı o de correspondência - 1820-24.

Livro de registro de documentos -1821 .

Livro de registro dos ofícios a presidência - 1876-80.

Livro de registro de previsões - 1804-07.

Livro de registro de ofícios para côrte - 1809-12.

Livro de registro de ofícios - 1823-24.

Livro de registro de ofícios -1824 .

Livro de registro de juizes de paz - 1833-34.

Livro de registro de atas do govêrno - 1821-22.

Livro de registro de coletoria - diversas - 1853.

Ofícios, decretos, cartas régias - 1823-26.

Maço de resoluçōes e orçamentos provinciais - 1838-40.

Ordem régias, mapas de anicuns - 1807-13. 
Maços de ofícios dirigidos ao provedor da fazenda -1850 .

Maço de leis e decretos imperiais - 1836-48.

Leis e decretos impressos e manuscritos - 1836-38.

Documentos das câmaras - 1828-37.

Projetos relatórios despachos - 1867-38.

Relatórios orçamcntos avisos ministeriais $-1850-52$.

Ordem imperiais e correspondência - 1843-46.

Documentos de despeza da tesouraria - 1850 .

Têrmos de avaliações de miunças - 1841-61.

Maço de originais de atas - 1839-75.

Registro de Patentes - 1820-49.

Registro geral de correspondência - 1845-61.

Autógrafos de leis, decisões legislativa - 1841-42.

Documentos de ministério de negócios do império - 1883 .

Cartas Régias - alvará - despachos - ofícios - 1820-25.

Cartas patentes - balanços de correio 1801-25.

Ofícios - cartas de cuiabá correspondência - 1801-25.

Regulamentos - requerimentos - 1801-25.

Mapas de quinto - 1801-25.

Requerimento de sesmaria - 1764-77.

Livro de registro da porta $-1871-72$.

Livro de registro da porta - 1869-71.

Livro de registro da porta -1868 .

Livro de registro da porta - 1866-68.

Livro de registro da porta $-1865-66$.

Livro de registro da porta - 1864-65.

Livro de registro da porta - 1862-64.

Ministério de negócios do império - 1878 .

Orçamentos - 1859.

Ministérios dos negócios da justiça - 1887.

Secretaria de policia da provincia - 1881 .

Correspondência - 1888.

Juizes de Direito - 1875-90.

Atos do govêrno - 1886 .

Relatórios - 1873.

Resoluções - 1879.

Ministério dos negócios da justiça - 1876-77.

Secção do palácio do govêrno - 1865-75.

Suplente do correio oficial - 1873 .

Secção do palácio do govêrno - 1866-77.

Documentos da marinha - 1855-68.

Atos do govêrro - 1890-91.

Ministério da agricultura -1861 .

Ministério do regócio do império - 1862-63. 
Receita da despesa - 1879-80.

Ministério de negócio da justiça - 1854-58.

Resolições - 1855 .

Ministério de negócio da justiça -1855 .

Leis do Brasil - 1808-22.

Leis do Brasil - 1823-26.

Leis do Brasil - 1826-29.

Leis do Brasil - 1830-31.

Leis do Brasil - 1832-70.

Leis do Brasil - 1872-79.

Leis do Brasil - 1880-83.

Desições do govêrno - 1850 .

Desiçōes do govêrno - 1855-59.

Desiçōes do govêrno - 1861-68.

Desições do govêrno - 1871-72.

Desiçōes do govêrno - 1874-77.

Desições do govêrno - 1880-86.

Repertório geral das leis do Brasil - 1847 .

Repertório geral das leis do Brasil - 1850 .

3. - Jornais do Século XIX.

Gazeta oficial - 1858 .

$O$ Tocantins - 1854-55.

Gazeta oficial - 1859.

Correio oficial - 1864.

Correio oficial - 1866.

Correio oficial - 1870.

Correio oficial - 1871.

Correio oficial - 1872 .

Correio oficial - 1873.

Correio oficial - 1874.

Correio oficial - 1875 .

Correio oficial - 1876.

Correio oficial - 1877.

Correio oficial - 1878 .

Correio oficial - 1879.

Correio oficial - 1880 .

Correio oficial - 1881 .

Correio oficial - 1885 .

Correio oficial - 1886 .

Correio oficial - 1887.

Correio oficial - 1888 .

Correio oficial - 1889.

Semanário oficial - 1899 . 